\title{
Design and Construction of A 50kg Capacity Furnace
}

\author{
Major Paul Aliemeke B. N. G. \\ Department of Mechanical Engineering, Auchi Polytechnic, Auchi
}

\begin{abstract}
The design and development of a 50Kg charcoal fired crucible furnace for melting aluminium and its alloys are presented. Importance of Metal melting furnaces cannot be overemphasized in industrialized and under industrialized countries. A detailed designed analysis was conducted to determine the various component sizes of the crucible furnace so to pave way for its construction. Majority of the materials used for the furnace construction were obtained locally. The blower capacity was determined to be air to ratio of 400:1 and $0.05 \mathrm{~m}^{3} / \mathrm{min}$. The designed furnace of overall volumetric capacity of $0.57 \mathrm{~m}^{3}$ accommodates a crucible pot which had a height and volume of $0.577 \mathrm{~m}$ and $0.0155 \mathrm{~m}^{3}$ respectively. The designed operating temperature of the furnace was $1200^{\circ} \mathrm{C}$ and maintained a heat transfer rate of $494.2 \mathrm{~W} / \mathrm{m}^{2}$ across the wall. The designed efficiency of the charcoal fired furnace was $59.35 \%$.
\end{abstract}

Keywords: Crucible, furnace, Charcoal, Volumetric capacity, Design, Efficiency

DOI: $10.7176 / \mathrm{ISDE} / 12-2-03$

Publication date: April $30^{\text {th }} 2021$

\section{Introduction}

Foundry technology is practiced in both urban and rural areas of Nigeria; the local foundry man digs a hole on the ground to take the shape of an oven, using coal or charcoal as fuel and makes use of a clay or metal pot as the crucible (Sani, 2015). The local foundry people use the crucible furnace for making of casting of different objects such as machines parts, domestic cooking pots of different sizes, serving spoons, frying pans, etc. Precise production of automobile spare parts and engine componenets are done effectively in our foundries (Asibeluo \& Ogwor, 2015).Virtually all manufacturing engineering based industries such as automobile, Machine tool, construction, communication, electrical, aviation, plumbing etc depend on foundry products(Asibeluo, 2015).

A furnace is an equipment used for melting of metals for casting and heat treating metals so as to influence their mechanical and physical properties (Sekar, Allesu \& Joseph, 2015). The importance of Metal melting furnaces cannot be overemphasized in industrialized and under industrialized countries.Nigerin entrepreneurs have always had the challenge of getting imported furnace so a result of high cost and scarce foreign exchange. Iron melting in Nigeria dates back to the Nok culture of 2000 years ago in the Middle belt area of the country while on the Southern plains, bronze casting has been practiced by the Binis for over a thousand years. Archaeologists have traced early iron works, blacksmith artifact and artistic castings to Ife (Golorunnishola, Ojaomo \& Onibon, 2019).

The inability to develop local content in the design and construction of relevant workshop and laboratory equipments has been a bane in research breakthroughs in Nigeria. The major problems associated with the old type open crucible furnaces used in the local foundries are:- The foundry man is exposed to heat and combustion products which are harmful to his health.

More than half of the heat escapes due to the open nature of the local furnace (Ndrika, 2004). These open crucible furnaces contribute to ecological problems, global warming and environmental degradation due to high demand of wood for charcoal production (Ndrika, 2002). The process consumes large quantities of fuel (charcoal) due to its low combustion efficiency and high heat loss (Olorunnishola \& Anjorin, 2016).

A crucible furnace that fires on spent engine oil which ordinarily would have been regarded as waste fluid was developed by Golorunnishola et al. (2019). The developed furnace has a capacity of $100 \mathrm{Kg}$ and an inner temperature of $1400^{\circ} \mathrm{C}$ with ambient temperature of $27^{\circ} \mathrm{C}$. The designed overall volumetric capacity of the crucible furnace was $0.1404 \mathrm{~m}^{3}$. The spent engine oil fired crucible furnace was able to finally attain an inner temperature off $1280^{\circ} \mathrm{C}$ as such was able to melt aluminium metel and cast iron. Similarly, Alanene and Olaruwaju (2010) in a bid to eliminate the use of electric power which is poorly generated in Nigeria designed and fabricated a diesel fired crucible furnace. The furnace had a pre-set temperature of $910^{\circ} \mathrm{C}$.

Also, a mini-electric arc furnace of a capacity of $5 \mathrm{Kg}$ was designed by Oyewale \& Olawale (2011) using locally made electrodes. The furnace was able to melt a cast iron rod at a temperature of $1150^{\circ} \mathrm{C}$.

The idea of relying on fossil fuel products to power furnaces in foundry workshops engenders the waste of financial resources and depletion of the world's mineral resources since energy plays a great role in boosting global economy. Recycling has a great economic and financial benefit in addition to its environmental imperativeness (Bafail et al., 2012). Metal recycling helps to preserve natural resource and use less energy during heating as against what is obtained in the manufacture of product from virgin raw materials ( Cui and Roven, 2015). 
This study which is aimed at the design and fabrication of a Charcoal-fired 50Kg Crucible furnace will utilize the viability of locally made charcoal to fire the proposed crucible furnace so as to reduce the cost of production and boost entrepreneurial penchant for foundry practice.

\section{Methodology}

In the design of the charcoal-fired crucible furnace major components such as crucible pot, air blower, furnace lining, fire nozzle, furnace drum and cover were used in the construction of the crucible furnace. The various component parameters such as: Air blower capacity, furnace drum diameter, minimum thickness of the furnace wall, maximum allowable working pressure for the furnace, change in length of the furnace, change in diameter of the furnace, change in volume of the crucible, amount of fuel burnt per hour, height of the combustion chamber and furnace efficiency were determined.

\subsection{Design specification for the Crucible furnace}

The design assumption put up for the various components of the crucible furnace are as stated:

i. Outlet pressure of blower is $1700 \mathrm{Mpa}$

ii. Speed of blower is 3000rpm

iii. Power rating is $3.0 \mathrm{Kw}$ and 220 volts

iv. Calorific value of charcoal is $29600 \mathrm{Kj} / \mathrm{kg}$

\subsection{Determination of Blower capacity}

The average rate of air flow of blower is $20 \mathrm{~m}^{3} / \mathrm{min}$

The average rate of fuel flow is $0.05 \mathrm{~m}^{3} / \mathrm{min}$

The air to fuel discharge ratio is $=20 / 0.05=400: 1$

The air to fuel discharge ratio of 400:1 was similar to the blower capacity calculated by (Asibeluo \& Ogwor , 2015)

\subsection{Design for crucible pot}

The volumetric capacity of the crucible pot was determined from the relationship between volume of crucible pot, density of aluminium and mass as given by equation (1).

$V_{c}=\frac{M}{\delta}$

Where $\mathrm{Vc}=$ volume of crucible

$\mathrm{M}=$ given mass of $50 \mathrm{~kg}$

$\delta=$ density

$\mathrm{Vc}=50 / 2710=0.0185 \mathrm{~m}^{3}$

The height of the crucible was determined using equation (2)

$V_{c}=\pi r^{2} h_{c}$

Where hc=height of crucible

$\mathrm{r}=$ radius of crucible taken to be $0.101 \mathrm{~m}($ Sani,2015)

$\mathrm{h}_{\mathrm{c}}=0.0185 / 3.142 \times 0.101^{2}=0.577 \mathrm{~m}$

Putting into perspective the crucible height of $0.577 \mathrm{~m}$ and charge diameter of $0.201 \mathrm{~m}$ it became practically imperative to assume a furnace length of $900 \mathrm{~mm}$ since the furnace height must be well above the crucible. This result was in consonance with Golorunnishola et al, (2019).

\subsection{Design for the furnace drum}

The volumetric capacity of the furnace drum which was considered to have height and diameter of $900 \mathrm{~mm}$ was determined using equation (3). The first angle orthographic projection of the furnace drum are shown in Figure 1 .

$V_{f}=\pi R^{2} H$

Where $V_{\mathrm{f}}=$ volume of furnace

$\mathrm{H}=$ height of furnace

$\mathrm{R}=$ radius of drum

$\mathrm{V}_{\mathrm{f}}=3.142 \times 450^{2} \times 900=0.57 \mathrm{~m}^{3}$

In determining the volume of combustible space, the radial distance of the flame gap was calculated using equation (4)

$R_{f g}=D_{f}-R_{t}-C_{d}-C_{t}$

Where $\mathrm{R}_{\mathrm{fg}}=$ Radial flame gap

$\mathrm{D}_{\mathrm{f}}=$ diameter of furnace 
$\mathrm{R}_{\mathrm{t}}=$ radial thickness of the refractory lining

$\mathrm{C}_{\mathrm{d}}=$ crucible pot diameter

$\mathrm{C}_{\mathrm{t}}=$ refractive cement thickness

$\mathrm{R}_{\mathrm{fg}}=900-420-202-40=238 \mathrm{~mm}$

The volume of the combustible space is determined using equation (5)

$V_{c}=\pi R_{f g}^{2} h_{s}$

Where $\mathrm{V}_{\mathrm{c}}=$ volume of combustible space

$\mathrm{h}_{\mathrm{s}}=$ height of combustible space

$\mathrm{V}_{\mathrm{c}}=3.142 \times 0.238^{2} \times(0.900-0.240)=0.117 \mathrm{~m}^{3}$
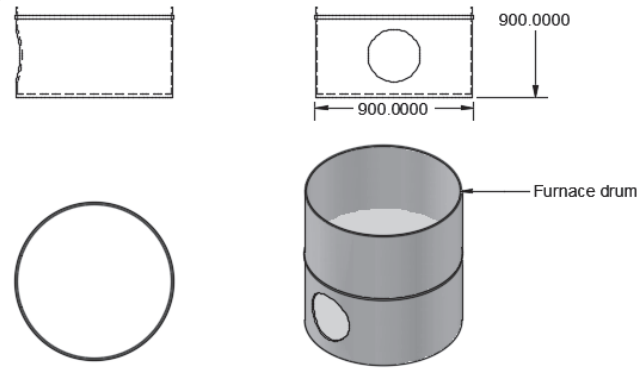

Figure 1: Orthographic projection of the furnace drum

\subsection{Design for refractory lining}

In order to check the transfer of heat to the surrounding and promote optimal retention of heat in the combustion chambers of the crucible furnace, refractory lining was arrayed within the furnace. The refractory lining used in this study comprised of Plaster of Paris (POP) material, Ant-hill soil, soil laterite and mortar (Asibuelo, 2015). A mixture of sodium silicate, Kaolin and water was applied as binder to fill the spaces. The inner and bottom surfaces of the furnace were lined with double layers of $125 \mathrm{~mm}$ bricks as shown in Figure 2.

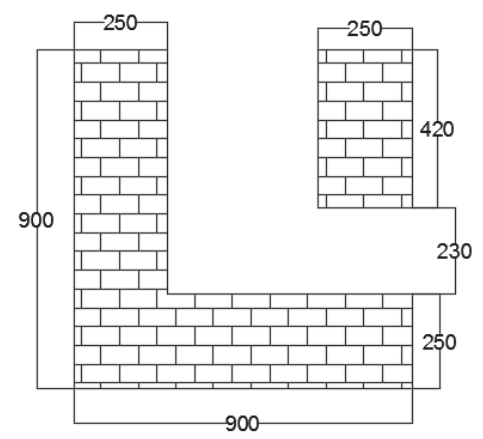

Figure 2: Crucible furnace wall lined with bricks

\subsection{Determination of the heat transferred through the furnace wall}

In calculating for the rate of heat transfer through the furnace equation (6) (Golorunnishola et al, 2019) was applied

$$
Q=\frac{A\left(T_{m}-T_{o}\right)}{\frac{L_{A}}{K_{A}}+\frac{L_{B}}{K_{B}}+\frac{L_{C}}{K_{C}}}
$$

Where $\mathrm{Q}=$ heat transferred

$\mathrm{A}=$ area of refractory bricks

$\mathrm{T}_{\mathrm{m}}=$ furnace maximum temperature $\left(1200^{\circ} \mathrm{C}\right)$

$\mathrm{T}_{\mathrm{o}}=$ Ambient temperature $\left(27^{\circ} \mathrm{C}\right)$

$\mathrm{L}_{\mathrm{A}}=$ thickness of P.O.P. refractory brick, $240 \mathrm{~mm}$

$\mathrm{L}_{\mathrm{B}}=$ thickness of mortar, $105 \mathrm{~mm}$

$\mathrm{L}_{\mathrm{C}}=$ thickness of metal sheet, $5 \mathrm{~mm}$

$\mathrm{K}_{\mathrm{A}}=$ Conductivity of POP refractory brick, $0.1185 \mathrm{~W} / \mathrm{m}^{\circ} \mathrm{C}$

$\mathrm{K}_{\mathrm{B}}=$ Conductivity rate of mortar, $0.48 \mathrm{~W} / \mathrm{m}^{\circ} \mathrm{C}$

$\mathrm{K}_{\mathrm{C}}=$ Conductivity rate of the metal sheet, $50.2 \mathrm{~W} / \mathrm{m}^{\circ} \mathrm{K}$ 


$$
\frac{Q}{A}=\frac{1200-27}{\frac{0.240}{0.1185}+\frac{0.104}{0.48}+\frac{0.005}{50.2}}=494.2
$$

The rate of heat transfer through the furnace lining is $494.2 \mathrm{~W} / \mathrm{m}^{2}$. This was found to be close to the values obtained by Sani(2015) and Asibeluo \& Ogwor (2015).

\subsection{Design for Furnace Efficiency}

The efficiency of the crucible furnace is the ratio of the useful heat output to the heat input as shown in equation (7) (Khurmi \& Gupta, 2005)

$$
\text { Efficiency }=\frac{\text { Total heat input }-Q_{v}}{\text { Total heat input }} \times 100 \%
$$

Where $\mathrm{Q}_{\mathrm{v}}=$ calorific value of charcoal $(29600 \mathrm{KJ} / \mathrm{kg})$

The energy required to raise the temperature of aluminium metal was calculated using equation (8) (Jain, 2007)

$$
\text { Energy }=M_{a} \times C_{h} \times T_{d}
$$

The parameters used in determining the efficiency are as follows

$\mathrm{T}_{\mathrm{d}}=$ Designed temperature of furnace $=1200^{\circ} \mathrm{C}$

$\mathrm{C}_{\mathrm{h}}=$ Specific heat capacity of aluminium $=0.904 \mathrm{Kj} / \mathrm{kg}$

$\mathrm{M}_{\mathrm{a}}=$ Mass of aluminium $=50 \mathrm{~kg}$

Energy required to raise the temperature of aluminium $=50 \times 0.904 \times(1200-27)=53019.6 \mathrm{Kj}$

The energy required to bring about a change of state is determined by using equation (9)

$E_{s}=M_{a} \times L_{f}$

Where $\mathrm{E}_{\mathrm{s}}=$ Energy involved in change of state of aluminium

$$
\mathrm{L}_{\mathrm{f}}=\text { latent heat of fusion of aluminium }(396 \mathrm{Kj} / \mathrm{kg})
$$

The energy required for change of state is $=50 \times 396=19800 \mathrm{Kj}$

Total heat input required to completely melt aluminium is $53019.6+19800=72819.6 \mathrm{Kj}$.

Thus Efficiency $=\frac{72819.6-29600}{72819.6} \times 100 \%=59.35 \%$

The theoretical efficiency of the charcoal crucible furnace is estimated to be $59.35 \%$. The efficiency increases with increased mass of metal (Asibeluo \&Ogwor, 2015)

\section{Result and discussion}

\subsection{Summary of designed parameters}

The various values designed for are summarized as shown on Table 1

Table1: Crucible furnace parametric values

\begin{tabular}{|l|l|l|}
\hline S/N & Parameter & Designed values \\
\hline 1 & Blower capacity & $0.55 \mathrm{~m}^{3} / \mathrm{min}$ \\
\hline 2 & Crucible pot height & $0.577 \mathrm{~m}$ \\
\hline 3 & Crucible pot volume & $0.0155 \mathrm{~m}^{3}$ \\
\hline 4 & Furnace volume & $0.57 \mathrm{~m}^{3}$ \\
\hline 5 & Radial flow gap & $238 \mathrm{~mm}$ \\
\hline 6 & Rate of heat transfer & $494.2 \mathrm{~W} / \mathrm{m}^{2}$ \\
\hline 7 & Furnace efficiency & $59.35 \%$ \\
\hline
\end{tabular}

\subsection{Modelling of the furnace}

The diagramatic modelling of the crucible furnace was done using Autodesk AutoCAD 2016. The isometric drawing and First angle projection of the furnace are shown in Figures 3 and 4 respectively. 


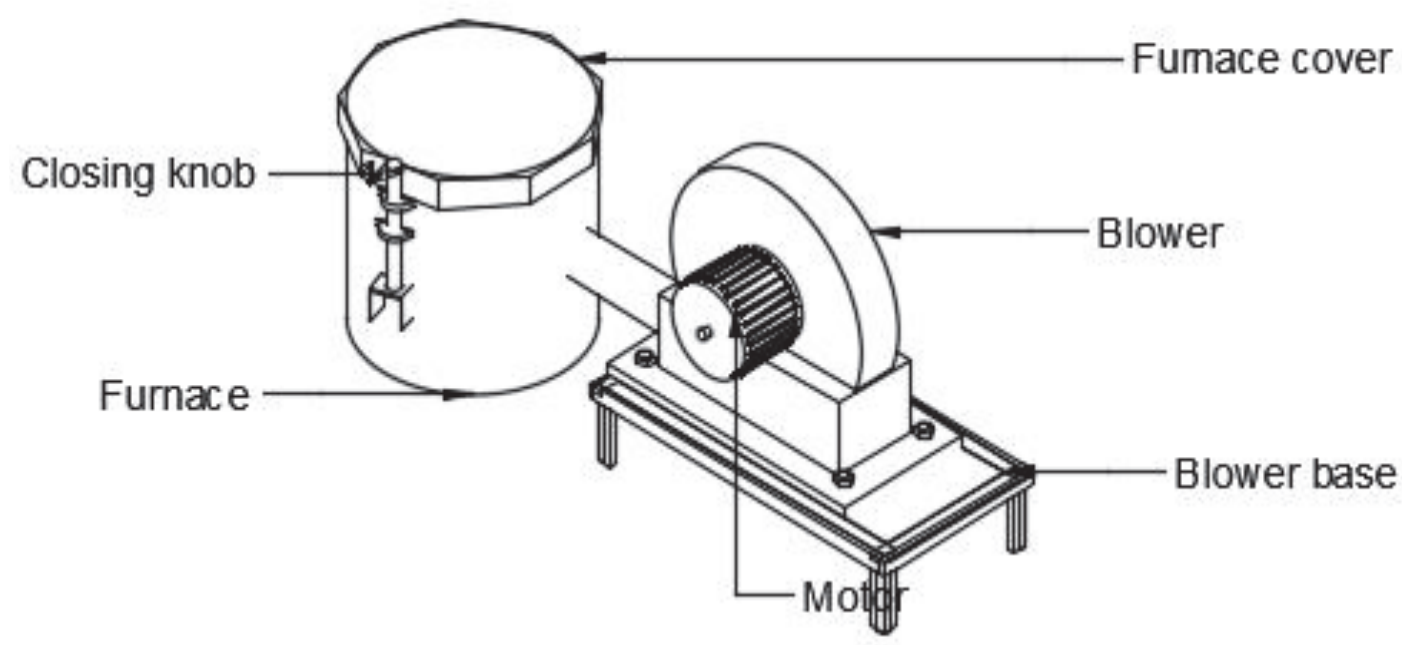

Figure 3: Isometric drawing of the Crucible furnace
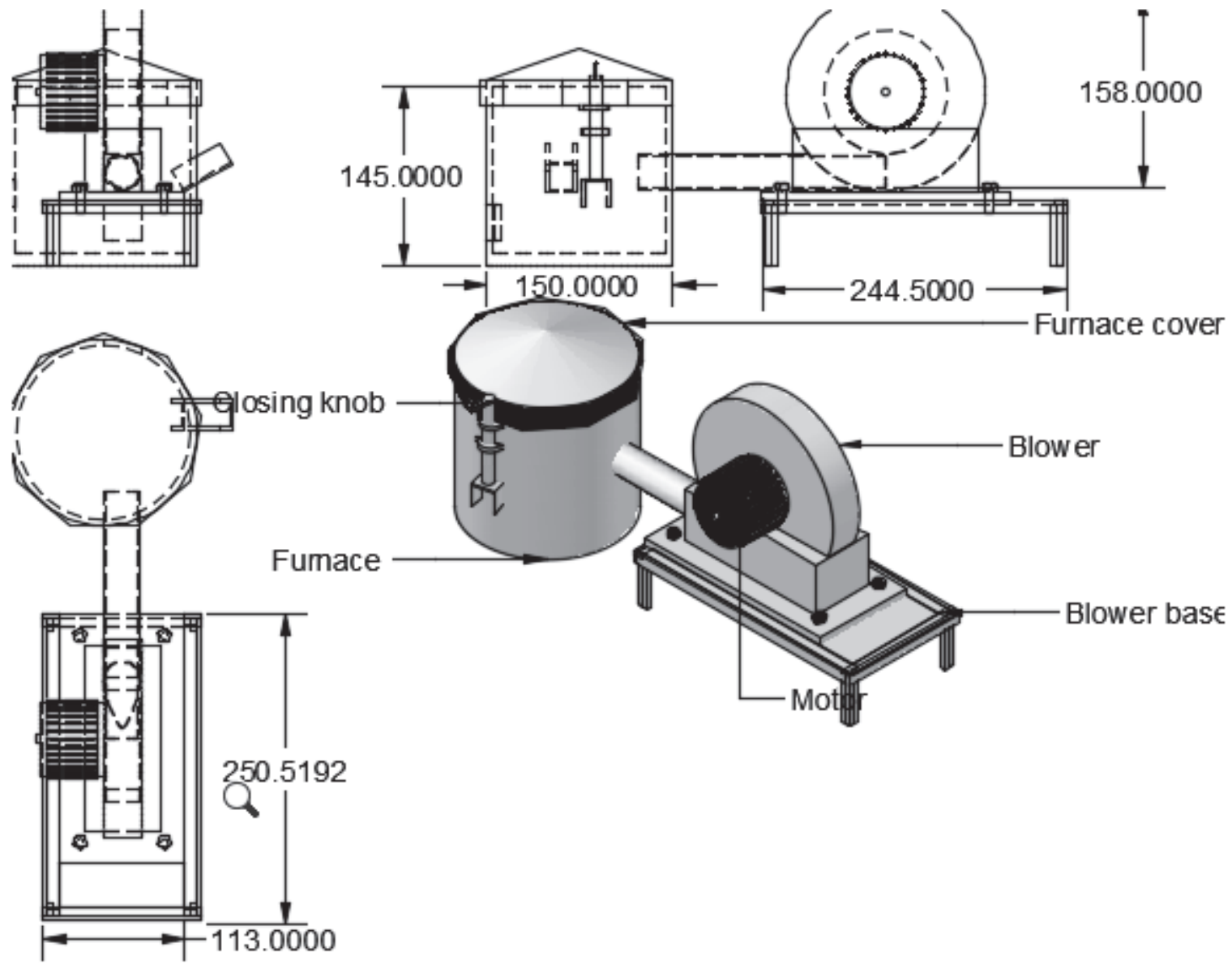

Figure 4: First angle orthographic projection of the furnace.

\subsection{Fabrication of the crucible furnace}

The crucible furnace was fabricated by applying the design calculations developed and summarized in Table 1 . The furnace drum was constructed using the $5 \mathrm{~mm}$ mild steel plate. The lining of the furnace using bricks was done after the construction of the drum so as to limit movement of the furnace after it has been brick-lined. The 
binder which consists of kaolin, sodium silicate and water was spread between the spaces to promote utmost cohesion among the bricks. The bottom of the furnace was lined with bricks before the two horizontal sides.

The furnace cover and the opening mechanism were constructed using $5 \mathrm{~mm}$ thick mild steel plate and 2 inch steel pipe respectively. The edge of the furnace cover was reinforced with $5 \mathrm{~mm}$ thick flat bar steel.Angle bars steel was used to braze the inner part of the cover so as to hold the refractory lining. The developed crucible furnace is shown in Figure 5.

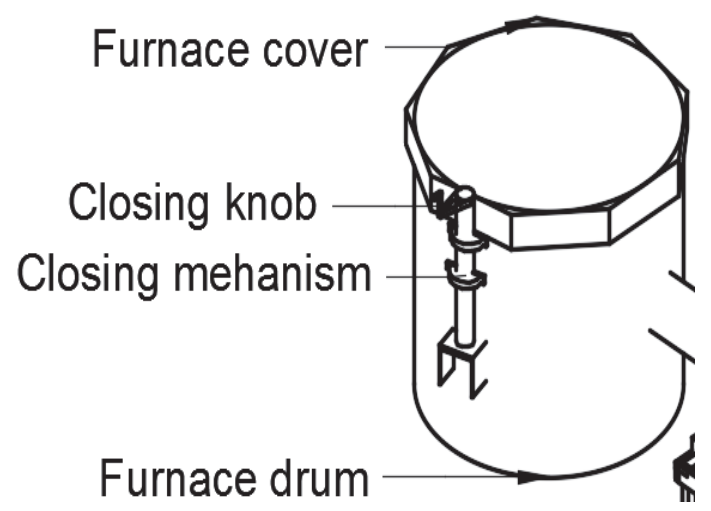

Figure 5: Developed crucible furnace

\subsection{Fabrication of the nozzle}

A solid support base which will bear the air blower, motor, pipes and burner( nozzle) was constructed using $10 \mathrm{~mm}$ thick angle bar. The nozzle was created from a $360 \mathrm{~mm}$ and $180 \mathrm{~mm}$ plate. The drawing of the nozzle is shown in Figure 6.

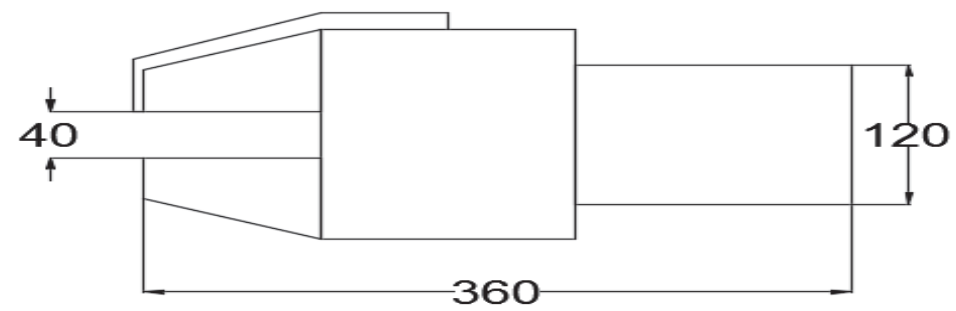

Figure 6: Schematic of nozzle

\subsection{Working Principle of the Crucible furnace}

The crucible furnace is preheated before firing it by igniting charcoal in the combustion chamber. The control valves of the diesel pipe and the air from the blower pipe are gradually opened to introduce drops of fuel and air under pressure. As the mixture of fuel and air blows over the charcoal oxidation takes place which culminates into combustion. The intense combustion leads to great increase of temperature. The furnace temperature can be read from an optical pyrometer placed close to the chimney of the furnace. While the molten metal temperature can be read from the digital thermocouple.

\subsection{Conclusion}

The $50 \mathrm{Kg}$ Charcoal fired furnace was designed and fabricated in the foundry workshop of Auchi Polytechnic, Auchi. On completion of the furnace it was noticed that the maximum temperature attained was $1200^{\circ} \mathrm{C}$. A furnace crucible which accommodated a capacity of $50 \mathrm{Kg}$ was well sustained in the performance evaluation. The blower capacity was determined to be air to fuel ratio of $400: 1$ and $0.05 \mathrm{~m}^{3} / \mathrm{min}$. The designed furnace of overall volumetric capacity of $0.57 \mathrm{~m}^{3}$ sustained a crucible pot of height and volume of $0.577 \mathrm{~m}$ and $0.0155 \mathrm{~m}^{3}$ respectively. The furnace wall attained a heat transfer rate of $494.2 \mathrm{~W} / \mathrm{m}^{2}$. The efficiency of the charcoal fired furnace was determined to be $59.35 \%$ which is close to the value obtained in Asibeluo \& Ogwor (2015).

\subsection{Conflict of interest}

The authors of this article have not declared any conflict of interest.

\subsection{Acknowledgement}

The authors of this article wish to appreciate the Management of Tertiary Education Trust Fund (TETFund), 
Abuja and Auchi Polytechnic, Auchi for providing the needed fund for this robust research. This type of collaboration and encouragement is necessary for sustainable development at the tertiary education level in Nigeria.

\section{References}

Alaneme, K. K. \& Olarenwaju S. O. , (2010). Design and Construction of a Diesel Fired Heat treatment Furnace, Journal of Minerals \& Materials Characterization \& Engineering, Vol. 9, No.7, pp.15-23

Asibeluo, I. S. (2015). Fundamentals of Foundry Technology and Forging Operation, Second Edition, CEE Emmy Ventures, Agbor, Nigeria

Asibeluo I. S. \& Ogwor O. E. (2015), Design of a 50Kg Capacity Cast Iron Crucible Furnace using Locally Available Materials, International Journal of Research in Engineering and Technology, Vol. 4, No. 3, pp. 525-531

Bafail, A.O., Jomoah, M. I. \& Noweir, M. H. (2012). Recycling Industrial Metal Wastes in the Kingdom of Saudi Arabia, Canadian Journal on Scientific and Industrial Research. Vol.3, No.4, Pp 56-65

Cui, J. \& Roven J. H. (2015). Recycling of Automotive Aluminium, Norwegian University of Science and Technology, Norway, International Symposium on Liquid Metal Processing and Casting, Santa Fe, New Mexico. pp. 389-396

Golorunnishola, A. A., Ojaomo, E. K. \& Onibon, G. L., (2019). Development of a Spent oil-fired 100Kg Crucible Furnace for Small Scale Foundry Industries, International Journal of Engineering Trends and Technology, Vol. 67, No. 4, pp. 103-107

Jain, R. K. (2007). Production Technology, Second Edition, Khanna Publishers, New Delhi

Khurmi, R. S. \& Gupta, J. K. (2005). A Textbook for Machine Design, , Published by Eurasia Publishing Limited and Rajendra Ravindra Printers Limited, New Delhi.

Ndrika, V. I. O. (2002), Development and Performance Evaluation of Charcoal Fired Cooking Stoves, Nigerian Journal of Renewable Energy, Vol. 10, No. 1, pp. 71-77.

Ndrika, V. I. O. (2004), Development and Performance Evaluation of Baking Oven using Charcoal as Source of Energy, Nigerian Journal of Renewable Energy, Vol. 12, No. 2, pp. 83-91.

Olorunnishola, A. A. G. \& Anjorin, S. A. (2016). Design, Construction and Testing of an Erthrophlemm Suaveolens Charcoal-fired Cupola Furnace for Foundry Industries in Nigeria, European Journal of Engineering and Technology, Vol. 4, No.1, pp.45-60.

Oyewole F. A. \& Olawole, D. O. (2011), Design of a Mini-Electric Arc Furnace, The Pacific Journal of Science and Technology, Vol. 8, No.1, pp. 35-45.

Sani, G. E. (2015), Design, Construction and Testing of a Charcoal fired Crucible furnace for Melting of $10 \mathrm{Kg}$ of Aluminium, M. Eng Thesis, Ahmadu Bello University, Zaria .

Sekar, K., Allesu, K. \& Joseph, M. A. (2015) Design, Construction and Performance Evaluation Of Multiple Casting Machine, Nigerian Journal of Technology, Vol. 32, No. 3, pp. 498-504 